\title{
SOLUTIONS OF THE BRITISH PRIVATE FINANCE INITIATIVE AS AN EXAMPLE OF THE PPP DEVELOPMENT AND PUBLIC-PRIVATE COOPERATION
}

\begin{abstract}
Public-private partnership (PPP) is an institution which enables to perform public tasks with the use of private partner's experience and competence. By appropriate preparation and implementation, it may bring a lot of benefits not only to the private partner and public entity but also to local community. An example of such preparation and implementation is the Private Finance Initiative (PFI) functioning in the UK.

The aim of this article is to evaluate the British PFI and to indicate specific legal solutions whose implementation would result in enhancing the attractiveness of PPP application. Therefore, the research problem is to answer the question: are there elements or features in the British PPP having significance to the implementation of public-private cooperation? According to the research hypothesis, in the PPP system functioning in the UK there are elements and features which indicate their key role in the implementation of the public-private cooperation.

The article presents PFI scheme in the UK and changes which have been made in this institution over the years. The example of PFI shows legal solutions targeted at improving the PPP application.
\end{abstract}

Keywords: Private Finance Initiative, public-private partnership, value for money

\section{Introduction}

British legal system is mainly characterised by common law and jurisdictional precedents which are complementary to legal acts established by the legislative body. For this reason, there is no statutory and complex regulation of the PPP initiatives. However, it functions as one of the most advanced and verified models of the PPP in Europe. PPP owes its comprehensive character to elaborated guidelines and good practice as well as to making standard principles of entering into such contracts by bodies responsible for the PPP development [Wachowska 2016, p. 11].

The concept of the PPP in the UK was an element of a modernistic look at the public sector at the turn of $80 \mathrm{~s}$ and $90 \mathrm{~s}$ of the previous century. As a result, private companies were allowed to compete for public tasks and in 1992 PFI was introduced, with the justification that it would enhance the efficiency of public sector by subjecting it to market principles, including competition [Falconer, McLaughlin 2000, p. 120].

PFI is defined as "a form of a private-public partnership connecting elements of public implementation of an investment programme, in which public sector acquires fixed capital from private entities, and outsourcing, in which public services are commissioned to private entities" [Allen 2001, p. 10]. When analysing the above definition, it may be stated that PFI is a form of PPP connected mainly with infrastructure investments implemented 
by private entities with concurrent commission to private entities a public service connected with a given infrastructure [Kopańska 2006, p. 2].

The aim of the PFI initiative was to enhance the engagement of the private sector in performing public utility services as well as to increase the possibility to finance them by the private sector financial institutions. At the beginning of 1990s public finance deficit influenced this aim because in exceeded 4\% of GDP (in 1993 it even amounted to $8 \%$ of GDP). At the same time the problems of public finance caused limitations of investment spendings, which at the beginning of 1990s were decreasing by $15 \%$ year by year [HM Treasury 2003, p.14]. Additionally, it was necessary to raise the level of public services quality, arising from social expectations and from the obligation to adjust to European norms [Sawkins, Dickie 2005].

\section{PFI Genesis}

PFI government programme proposed in 1992 was designated to enterprises which remained public after the privatisation period, as an idea joining tenders to buy capital goods with the concept of long-term purchase of services from the private sector [Bitner 2003, p. 25]. The first years did not give satisfactory effects. Therefore, in 1994 a principle was introduced that no public project would be accepted without conducting a survey on the possibility to implement it through the PFI mechanisms. The obligation to verify whether it was cost-efficient to implement every planned public investment as PFI, with the priority over other models, was abolished in 1997 [Allen 2016, p. 16].

Owing to the PFI in the UK since the start of its operation till April 2012, 550 projects in different economy sectors were implemented, whose value amounted to EUR 56 billion [European PPP Expertise Centre Publication 2012]. From the practical point of view, PFI has become a flexible tool in implementing the investments in the fields such as housing, building schools, hospitals, prisons as well as public transport - roads, motorways, underground, or investments aimed at a limited number of receivers such as a defence simulation programme or flight control [HM Treasury 2016].

In connection with allegations regarding the issue of cost-effectiveness and efficiency of the binding PFI formula [HM Treasury 2012], in 2012 it was decided to modify it. It was noticed that in many cases this institution was not sufficiently adjusted to the needs of public entities. The main disadvantages of PFI were [Rachon 2014, p. 27]:

- too long time and too high costs of procurements made within PFI for the public party;

- improper risk division between public and private parties, most often leading to excessive burden on the private investor, which caused too high costs of the projects;

- windfall profits of the private party which sometimes happened to appear;

- wrongly applied PFI during the implementation of the investments which were not appropriate for this model, what caused that the projects did not bring particular value added.

As a consequence, PF2 was implemented. The change had evolutional character with maintaining essential elements typical to PFI, recognising them as the basis of this formula functioning. The most significant of these basic elements was to require the partner representing the private sector to [Kargol-Wasiluk 2013, p. 75]:

- integrate designing, constructing and maintaining the structure which is the subject of cooperation in order to achieve a comprehensive solution;

- apply a solution which will to the greatest extend allow to achieve the final result defined by the public body and to provide the services on the basis of a detailed remuneration mechanism; requirements of the public partner regarding the project do not concern initial parameters determining its implementation (i.e. concerning project, specification) but concentrate on the expectations regarding the final effect, i.e. parameters of the provided service (e.g. the capacity of a hospital to accept a particular number of patients, adjusting a prison to accommodate particular categories of prisoners);

- obtain funds mainly from private entities and to conduct due diligence analysis of the project to minimise the risk of failure [Buisson 2013, p. 3].

As it was mentioned in the above definition, PFI is a contract between public and private entities. The private entity is described as a special purpose vehicle (SPV). Within PFI, the competences of SPV include organising funds for the initial construction phase with private sector capital share as well as credits incurred by the private entity. In this type of contracts, remuneration for the SPV 
is a unified payment, i.e. such which will be adequate to the amount of the incurred credits with interests, paying liabilities towards shareholders and which is equivalent to the services made. Remuneration is periodic and is paid after finalising the implementation of the structure and starting the services and is continued till the end of the contract.

It needs to be emphasised here that in the UK there are standardised rules of PFI contracts (Standardisation of PFI Contracts - binding version is 2013, SoPC) [Wachowska 2016, p. 12].

SoPC directs the manner in which PFI contracts are prepared, what allows to adjust it to particular circumstances of a specific undertaking, however it does not give a ready-to-use, general model of the contract. The basic SoPC aim is to:

- implement in the contract proper for the current PF2 risk-share,

- present example contract provisions (both obligatory as well as optional), complement some gaps in contracts standardisation,

- reduce the length of PFI contracts procedure by creating a standard approach in many issues upon which the parties may agree without long negotiations [ HM Treasury 2012, p. 2].

\section{Private Finance Initiative}

Undertaking in the form of PFI has given the UK the position of a pioneer and a world leader in investment activity in the form of PPP, which since the start has amounted to 980 projects [Grzybowski 2013, p. 62].

An essential PFI element were national bodies created by the government initiative, which supported PPP development in the UK. Currently, the unit responsible for PPP is Infrastructure UK (IUK). Its actions are mainly focused on long-term investments of the private sector. Nowadays, IUK is a body conducting PPP policy, spreading good practice and enforcing guidelines such as SoPC. Additionally, it supervises strategic management over PFI initiative, advises for ministries as well as verifies applications to accept exceptions from the standardised provisions covered by SoPC.

In 2010 Efficiency and Reform Group was established and a year later within it - Major Projects Authority (MPA), managing important government PPP projects. But the final result of the PFI development in the UK was joining
IUK and MPA on 1 January 2016 within Infrastructure and Projects Authority (IPA), which focuses on advising on infrastructure, implementation and support of the main projects and its actions spreads over all government sectors.

Another element of PFI functioning is conducting value for money (VfM) analysis. VfM indicator is a basic criterion of the project efficiency, which is a relation of benefits obtained by the public sector and taxpayers from an undertaking and its costs [Matuszewska 2011, p. 25-32]. The analysis consists in researching whether indicated risks associated with public tasks implementation do not entail excessive costs for the public sector [Bitner 2003, p. 25].

To better research the efficiency of a project within PFI, a three-stage VfM assessment has been introduced [HM Treasury 2016, p. 5], which is to conduct:

- evaluation on the programme level which is to ensure that only projects suitable to be implemented though PFI are selected and that they will guarantee a satisfactory VfM level;

- evaluation on the project level which is to preliminary estimate the undertaking according to Outline Business Care (OBC), which should be ended by announcing the information about the intended procurement in the Official Journal of the European Union (OJEU);

- evaluation on the procurement level which is to ensure competitiveness and real connection of the planned undertaking with market reality.

Ensuring profitability of the PF2 projects higher than public procurement has been a significant aspect and VfM is an important element for conducting PF2 undertakings. Its analysis is essential for decisions forming the contract regarding the division of risk, shaping remuneration of the private partner, financing, etc. Conducting such analysis is the obligation of the public party, since only well-made VfM analysis may in reality influence the conditions to successfully carry out the undertaking within PPP.

Another issue which needs to be raised is the creation of a special purpose vehicle (SPV), i.e. a company designated to manage a PFI investment. SPV is usually set up and financed by the private entity, in the form of a company with the participation of an investor-shareholder. This entity invests $10 \%$ of the capital needed and the remaining $90 \%$ ensures a creditor, e.g. a bank or a group of banks. 


\section{PFI Contracts}

Long-term character of the PFI contracts in relation to financial liabilities, which are not subjected to changeable economic conditions, may result in their profitability becoming obsolete in the long-term and in such situation arises the need to change or terminate the contract. There are three possible types of PFI contracts modifications:

- termination;

- a change made by the change protocol;

- variation having more serious character than change.

The cause to terminate the contract may be: the lack of VfM, downward pressure and budget limitations, disappointment with the SPV results, decrease of the social need for services, etc. Contract termination may appear in the following situations:

- private partner's fault (when the service is not provided, a particular limit of payment reduction in connection with low quality of the service is reached, and sometimes also as a general rule of material breach of the contract);

- public partner's fault (when the is a lack of payment or material breach of the contract);

- or in connection with force major.

Additionally, public entities have the possibility to terminate the contract without giving the reason, e.g. the right to stop the infrastructure built by the private partner.

When the contract is terminated, the structure being the subject of the PFI remains in the possession of the public partner regardless the cause of the contract termination. However, when the responsibility for the termination lies with the public partner, he is obliged to cover the costs of the credit, to pay off the shareholders of the undertaking, to cover severance pays, liabilities for subcontractors or other costs and damages which the private partner bears in connection with this termination. When it is the private partner who causes such contract termination, he has the right to keep the part of the remuneration which corresponds to the work done by him and kept by the public partner and the public partner becomes the owner of the subject of the contract. However, it is desirable for PFI contracts to regulate in advance who is the owner of the subject after the contract is ended and in the case of its termination, since this element significantly impacts cost evaluation of the project and thus VfM.
Another modification form is the possibility to limit the benefits under the contract, to change the structure of financing or even to change the contract itself. It may be done by making a change protocol and it concerns the scope of the services performed by the private partner. The change protocol is to create a complete procedure which should be applied to change the scope of the PFI contract and which should include steps starting from suggesting a particular change, its valuation and acceptance and finally its implementation. It does not have to pre-determine the scope or the conditions of the change. In the situation when the changes are proposed by the public partner, the contractor may refuse to conduct them only in specific cases, i.e. unlawfulness, essential negative impact on the possibility to provide services, unfeasible time of the change, threat to the life or health. Whereas, when the changes are initiated by the private partner, the public partner may accept them or not.

Besides a change conducted through the change protocol, a contract may be modified by annex. This type of change is called variation and concerns, for example: financing of the undertaking, too numerous and too complicated changes to be made by the change protocol. This type of modifications usually requires the consent of the creditor participating in the SPV financing. Taking into consideration the fact that PFI contracts, being long-term, are subjected to changeable market conditions, which may decide about significant transformation of demand for services being the subject of PFI, therefore changes are inevitable. Due to established change procedure, the chances to conduct them quickly and efficiently are bigger.

A key element of the PPP is efficient risk transfer to the private partner in such a way that it should encourage to provide services at the highest level. Risk transfer to the private partner is at the same time motivation to identify and manage risks appearing in the project as well as to analyse them. However, risk-share must be made is such a way as to ensure achieving VfM of a given project. This condition will be fulfilled if particular risks are to be assigned to the entity which will cope with them successfully. It should be emphasised that improper risk transfer to the private entity may result in the increase of the services costs for the public partner, influencing at the same time VfM.

British experience indicates how important is the awareness of connecting risk-share with general cost of the PPP 
undertaking as well as the withdrawal from the initial tendency to shift the biggest amount of risk to the private partner. Hence, the basis of risk-share must be a reliable analysis of the ability to bear risk at the lowest cost.

Unitary payment, i.e. the way in which the money is transferred to private partner, is a significant element of the PFI formula. It begins when the services start and the initial financing of the investment necessary to provide the services lies with the private partner. This type of payment shifts directly into the risk-share of private and public partners, discussed above. This PFI element is obligatory in the contract according to the standard principles of PF2 contracts [HM Treasury 2012 p. 157]. The amount of period payments may depend on the quality level of the services and should not be in different amounts.

\section{Conclusions}

The analysed British PPP system includes elements and features which are of key importance in the successful public-private cooperation. Additionally, some solutions seem to be significant due to their potential to minimize PPP barriers.

The obligation of the public entities designing PPP undertakings is the VfM analysis. It is essential the verify the project cost-effectiveness. Such analysis is to firstly verify whether a given type of investment should be conducted as PPP and then to design the undertaking in such a way as to ensure the biggest general cost-effectiveness with regard to particular conditioning of a given project (what should result in, e.g. conclusion how optimal risk-share should look).

The success of PPP implementation in the UK was influenced by establishing a national unit coordinating PPP development on political and strategic level, preparing guidelines for project implementation, offering content-related support for entities conducting PPP.

An element characteristic to PPP solutions is the construction of the private partner's remuneration as a period remuneration of one type, payable from the moment the service is provided. It depends on meeting the standard of services determined in the contract in such a way that in the case of not complying with it, remuneration for a given period is reduced.
The success of PPP is also influenced by a proper division of risk between the private and public partners. In connection with the above-mentioned element of remuneration, the risk connected with demand on the services in borne by the public partner. It is also necessary to transfer particular risks to the private partner so that the risk-share is more balanced.

Standardisation of PPP contracts, prepared by a national unit responsible for PPP, is of key importance in the British systems. It should be emphasised that it does not have the form of a ready-to-use and universal contract but it contains a description of the clauses which must be included in the PPP contract and which are essential to the relations between partners, financing, duration time, risk-share, etc. Standardisation indicates in what way particular contract provisions should be formulated depending on the circumstances.

When analysing PPP investments in the British model, also SPV seems to be an important element, since the project and the capital contribution of the shareholders are its assets. The credit granted by institutions financing the project is secured on these elements.

\section{Bibliography}

Allen G. (2001), Private Finance Initiative, House of Commons Research Paper 01/117.

Analiza prawna - Regulacje partnerstwa publiczno-prywatnego w wybranych krajach Unii Europejskiej i prawie polskim - możliwości zmian [online], www.mc.bip.gov. pl/rok-2016/analiza-prawna-regulacje-partnerstwa-publiczno-prywatnego-w-wybranych-krajach-unii-europejskiej-i-prawie-polskim-mozliwosci-zmian.html.

Bitner M. (2003), Modele partnerstwa publiczno-prywatnego w krajach Unii Europejskiej, "Finanse Komunalne" no. 8.

Building better partnerships. The final report of the Commission on PPP 2001 [online], www.ippr.org/files/images/media/files/publication/2011/05/cppp_1234.pdf.

European PPP Expertise Centre, United Kingdom - England. PPP Units and Related Institutional Framework, June 2012 r., www.eib.org/epec/library/index.htm.

Falconer P.K., McLaughlin K. (2000), Public-private partnerships and the «New Labour» government in Britain, [in:] S.P. Osborne (red.), Public-private partnership. Theory and practice in international perspective, Routledge, United Kingdom. 
From PF1 to PF2: the reform of the Public Private Partnership model in the UK, "Norton Rose Fulbright LLP", Buisson A. 2013, [online], www.ppp.worldbank.org/ public-private-partnership/library/pfi-pf2-reformpublic-private-partnership-model-uk.

Grzybowski W. (2013), PPP - realia czy mrzonki?, "Przegląd Komunalny" no. 1(256).

HM Treasury A new approach to public private partnerships, 2012 [online], www.gov.uk/government/uploads/ system/uploads/attachment_data/file/205112/pf2_infrastructure_new_approach_to_public_private_parnerships_051212.pdf.

HM Treasury Standardisation of PF2 Contracts. Draft, 2012 [online], www.gov.uk/government/publications/ private-finance-2-pf2.

HM Treasury Value for Money Assessment Guidance, 2006, [online], www.gov.uk/government/publications/ procurement-and-contract-management.

Kargol-Wasiluk A. (2013), Doświadczenia i dobre praktyki brytyjskie $w$ zakresie ppp - relacje $z$ wizyty studyjnej w Wielkiej Brytanii, "Biuletyn Partnerstwa Publiczno Prywatnego" no. 9.
Kopańska A. (2006), Partnerstwo publiczno-prywatne wzory brytyjskie. Czego można się z nich nauczyć?, "Studia Regionalne i Lokalne" no. 3(25).

Matuszewska A. (2011), Możliwość wykorzystania partnerstwa publiczno-prywatnego $\mathrm{w}$ komunikacji miejskiej w Polsce, rozprawa doktorska, Uniwersytet Ekonomiczny w Poznaniu, Wydział Ekonomii, Katedra Teorii i Historii Ekonomii [online], www.wbc.poznan.pl/Content/186563/MatuszewskaAnnaS4245.pdf.

PFI contracts-changes, variations and terminations, a practical comment available after logging [online], www.lexisnexis.com/uk/lexispsl/bankingandfinance/ document/391290/5D5H-YVP1-F185-S47W-00000-00/ PFI_contracts_changes_variations_and_terminations.

Rachoń H. (2014), System PPP w Wielkiej Brytanii i Holandii, "Biuletyn partnerstwa publiczno prywatnego" no. 10.

Sawkins J., Dickie V. (2005), Affordability of Household Water and Sewerage Services in Great Britain, "Fiscal Studies" no. 2. 